\section{Decision Making under Ignorance and Product Disclosure: Implications in Buying Insurance}

\author{
Wesley Mendes-Da-Silva ${ }^{1}$ (D) \\ Cristiane C. Gattaz ${ }^{2}$ \\ David V. Gibson ${ }^{3}$ (i)
}

\begin{abstract}
Purpose - The subject of making choices under risk has been studied based on the assumption that decision makers are fully informed. However, in real life situations individuals frequently need to make choices without the benefit of essential information. This study analyzes decision making in the absence of information about the probabilities of losses and potential impacts, which constitutes a context of ignorance, or alternatively making choices under risk or uncertainty.
\end{abstract}

Theoretical framework - This study is supported by theoretical aspects related to decision making under ignorance, specifically within the context of buying insurance.

Design/methodology/approach - We used One Way ANOVA and regressions based on the data collected from two experiments regarding the willingness to acquire extended warranties for electronic equipment, which involved the participation of over 130 volunteers.

Findings - Our findings suggest that the absence of economic information deficient disclosure - makes the cost of insurance relevant to the consumer and is negatively associated with the propensity to acquire it. In addition, the cost of repairs and the probability of equipment breaking increase the propensity to acquire an extended warranty.

Practical \& social implications of research - By making information relevant to consumption decisions and accessible in a transparent manner, agents can induce a surge in consumption, making the market more efficient and society more resilient in the face of risks.

Originality/value - This study may be the first to provide empirical evidence regarding the purchase of insurance within a context of ignorance in emerging markets.

Keywords - choices under ignorance, insurance, risk aversion, uncertainty, resilience.

1. Escola de Administração de Empresas de São Paulo da Fundação Getulio Vargas, São Paulo, Brazil

2. University of Texas at Austin, IC Institute, Austin/Texas, United States of America

3. University of Texas at Austin, IC Institute, Austin/Texas, United States of America

How to cite:

Mendes-Da-Silva, W., Gattaz, C.C., Gibson, D.V., (2021). Decision Making under Ignorance and Product Disclosure: Implication in Buying Insurance. Revista Brasileira de Gestão de Negócios, 23(4), p.571-585
Received on:

07/04/2020

Approved on:

04/15/2021

Responsible Editor:

Prof. Dr. Sebastian Molinillo

\section{Evaluation process:}

Double Blind Review

\section{Reviewers:}

Solon Bevilacqua; Marcelo Santos

Amaral

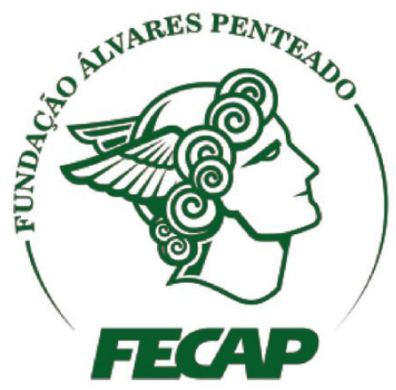

Revista Brasileira de Gestáo de Negócios

https://doi.org/10.7819/rbgn.v23i4.4130 


\section{Motivation}

The standard choice paradigm is supported by the assumption that individuals form their preferences between alternatives characterized by probabilities and results, as pointed out by Kleindorfer et al. (1993). However, one question which seems inevitable is: what happens when, in a real-world situation, there is no notion of probability, let alone the consequences of a given event? This situation assumes the existence of a context of ignorance (Health $\&$ Safety Executive, 2001; Maskin, 1979; Aven \& Steen, 2010; Tchiehe \& Gauthier, 2017). In parallel, Thaler and Tucker (2013) point out that studies that focus on the level of the individual tend to be more relevant, given that they represent a new class of products, with a potential value of US\$ 4.1 trillion based on new internet supported technologies (World Economic Forum, 2012).

In this study, we examine whether the absence of relevant information in decision making regarding a given type of insurance influences the judgement of individual consumers. We specifically examine whether information related to the probability of equipment breaking, as well as the cost of repairing it, influences the willingness of an individual to acquire an extended warranty. We also verify the justifications presented by individuals in their decisions to buy (or not to buy) a warranty.

This topic is of interest not just to researchers, but also to managers in durable goods industries and insurance, as well as regulatory agents (Din, Abu-Baka, $\&$ Regupathi, 2017). Kunreuther et al. (2013a, 2013b) argue that the insurance market has an explicit condition for growth, since companies that offer protection know the demands of this type of financial product, and consumers know the services provided by insurance companies. It is within this context that a lack of necessary information to make economic decisions receives greater attention, above all in markets in which the typical level of formal education is reduced, and even in better educated individuals, there appears to be a lack of knowledge of these financial products (Hastings \& Tejeda-Ashton, 2008; Lin, Hsiao, \& Yeh, 2017).

Our research design employs data collected through two experiments, featuring the participation of more than 130 volunteers. The individuals were divided into two groups and participated in their data collection sessions at different times. The first group received information $a$ priori and answered a group of questions regarding their willingness to buy a warranty. The other group began the experiment without the information relevant to their buying decisions and answered the same questions. We conducted tests via One Way ANOVA and regressions based on these data.

Our study offers two main results. First, considering the observations in aggregate, the availability of information about the probability of a product breaking, as well as the cost of repairing it, does not seem to significantly influence the willingness of individuals to acquire a warranty for electronic equipment. This suggests that typically people do not alter their willingness to acquire electronic equipment warranties in a significant manner, no matter whether they are making their decisions under ignorance or not. Second, our findings suggest that under ignorance higher warranty premiums inhibit the willingness of individuals to acquire this protection. This suggests that, if individuals have information about the probability of the equipment breaking and its repair costs, higher premiums do not significantly influence consumer willingness to acquire this warranty.

This study makes various contributions to the literature. It contributes to the literature regarding descriptive models of decision making, bearing in mind that we present evidence of individual behavior within contexts of ignorance. In addition, it makes a contribution to the normative theory of choice, in that more studies of decisions made under ignorance in institutional environments which are characteristic of emerging markets still merit research efforts. In dealing with the prescriptive implications of individual choices, this work contributes by providing consumers with information regarding the probability of electronic equipment breaking and its associated repair costs. It also contributes to the work of regulators, because it provides evidence of the potential impacts of programs that promote product disclosure, whether they are durable goods or financial services offered by insurance companies.

\section{Theoretical and Empirical Underpinnings}

Product disclosure is information provided to the consumer about a product's functionality and/or cost, normally during or after a transaction. Effective disclosure can help improve consumer choices, first by providing information about key aspects of the product in an engaging and understandable form, and second by helping consumers compare alternative products. 
Consumer engagement is the fundamental function of disclosure. Financial service products usually have difficulty in attracting engagement due to their abstract and intangible nature (Oxera, 2014). There are a series of products and services that consumers do not use sufficiently, and we can include insurance products in this group.

The distinction between risk, uncertainty, and ambiguity constitutes an important topic in the field of decision making at the level of the individual (Rubaltelli, Rumiati, \& Slovic, 2010; Desrochers \& Outreville, 2020). Knight (1921) is thought of as the first author to establish the distinction between these three concepts, and the results obtained by Arrow and Hurwicz (1977) were considered innovative at the beginning of the 1950s when they proposed properties of rationality. Since the work of Pratt (1964) and Arrow (1965), risk aversion within the context of economic decisions has been considered using theoretical and empirical models. In addition, according to Cabantous, Hilton, Kunreuther, and MichelKerjan (2011), ever since the work of Ellsberg (1961), the literature regarding questions related to ambiguity concerning probabilities within the context of decision making has received growing attention. Since then, a line of research has been developed concerning how individuals make decisions in the face of risk, uncertainty, or ambiguity (Camerer \& Weber, 1992; Sokolowska \& Zaleskiewicz, 2020).

\section{I Disclosure and financial product consumption decisions}

The theoretical aspects of decision making under ignorance have been addressed by the economic literature over the past few decades (Benítez, Carpitella, Certa, Izquierdo, \& Giang, 2015; Maskin, 1979). According to Giang (2015), ignorance and probability are opposite states of knowledge. On one hand, probability is derived from the knowledge of everything that can be reasonably known about a phenomenon whose results can be modeled as a random event. Ignorance, on the other hand, consists of a singular state of knowledge characterized by a complete lack of knowledge, or by the possession of no information regarding the phenomenon of interest. The main purpose of disclosure is to assure that the consumer has access to all information relevant to the buying decision (Office of Fair Trading, 2010). The finance literature has already documented arguments concerning the associations between the disclosure of relevant information and buying decisions regarding financial services (Agarwal, Chomsisengphet, Liu, \& Souleles, 2015; Kunreuther et al., 2013a, 2013b; Robb, Babiarz, Woodyard, \& Seay, 2015).

Bertrand and Morse (2011) argue that the design of an informational apparatus oriented towards the psychological aspects of individuals can induce choices at lower cost. Through a field experiment with payday loan stores in the United States, these authors concluded that information plays a central role in the financial costs assumed by the consumer. In particular, the results of Bertrand and Morse (2011) suggest that when a financial institution opts to emphasize the costs associated with rolling over a debt, consumer acceptance of credit decreases significantly in subsequent months.

An illustration of the interest of governments in the role that appropriate information can play in the quality of consumer decision making in terms of financial services can be observed in the United States. An agency called the Consumer Financial Protection Bureau <http:// www.consumerfinance.gov $>$ has maintained a consumer information program called 'Know Before You Owe' $<$ http://www.consumerfinance.gov/know-before-youowe/>, which is designed to help mortgage consumers better understand their financing alternatives, thus avoiding unexpected costs.

Various products, including financial services, have attributes that make disclosure of their characteristics more effective. In this sense, disclosure which is more effective i) engages consumers, ii) helps consumers understand the product, and iii) helps consumers make good decisions. In terms of what limits the effectiveness of product disclosures, Oxera (2014) lists the following items:

- Complex information: The complexity of some financial products, combined with the limited attention and cognitive ability of some consumers, highlights the relevance of product disclosure that helps consumers make appropriate decisions (Ben-Shahar \& Schneider, 2011; Burke \& Fry, 2019; Fichera \& von Hinke, 2020; Sicherman, Loewenstein, Seppi, \& Utkus, 2014).

- $\quad$ Difficulty in taking part: Financial services which are described in a summarized manner induce reduced attention on the part of consumers. Various disclosure techniques, such as reminders, can contribute in a positive manner (Laibson, 1997; Sicherman et al., 2016). 
- Uncertainty in terms of costs and returns: Some types of financial products involve immediate financial onuses and possible future gains, with some risk. Within this context, possible cognitive biases can lead to difficulties in the understanding of financial products, even when disclosure is adequately addressed. Thus, the value of a financial product can be affected by the format in which the information is presented to the consumer, or even consumer experiences with recent events (Diacon \& Hasseldine, 2007; Howlett \& Pagano, 2008).

- Multiplicity of prices: At least one part of the complexity attributed to financial products is the multiplicity of fees charged to consumers over the useful life of these products, such as fees to open credit and pay off the financing of real estate, in addition to the remuneration rates for the capital borrowed. One part of the literature has dedicated itself to investigating how the disclosure of additional costs can affect consumer decisions (Woodward \& Hall, 2010).

- Percentages: A common format used in financial products is percentages. Percentages are used to present administration fees for investment funds and calculate the cost of credit and insurance claims, among other items. And frequently the costs and/or returns of financial products are calculated through the aggregation of percentages, which adds complexity to the decisions of some consumers (Hastings \& Tejeda-Ashton, 2008).

- Specific value to the consumer: The value and/or cost of a financial product depend on how the consumer uses it. While a financial product can be seen as appropriate for a given consumer, it may not effectively meet the needs of another, which implies greater difficulty in standardizing disclosures (Brown, Kling, Mullainathan, \& Wrobel, 2008; Bertrand \& Morse, 2011).

- Disclosure of a product's use: The total costs and benefits of a given product depend on its attributes as well as its potential uses. Disclosure plays a role in reducing distorted perceptions of the attributes and potential future uses of a product. The regulation of disclosure has concentrated on product attributes, to the detriment of more effective disclosure of its uses (Hogath \& Merry, 2011).

\subsection{Willingness to buy insurance and risk aversion}

In terms of empirical evidence of risk aversion, with a particular focus on the demand for various types of insurance, the works of Banks, Bassoli, and Mammi (2019), Din et al. (2017), Fang (2020), Jindal (2015), Laura, Mihai, and Mihaela (2020), Lin et al. (2017), Mumo and Watt (2019), and Outreville (2014) offer a thorough review of the current literature. The scope of our work is based on that of Hogarth and Kunreuther (1995), which discusses cost-benefit analysis and what would be the rules for making decisions in terms of buying insurance. These authors assume that when individuals are properly supplied with precise information regarding the probabilities of potential losses, they decide based on a comparison of the expected costs and the warranty costs, as in Equation (1).

$$
y=f(q \cdot r-c)
$$

where: $y$ represents the probability that the individual states that he or she is willing to acquire an extended warranty, $q$ represents the estimated probability that the product will break, $r$ is the estimated cost of repair, and $c$ is the cost of the warranty (premium paid for the insurance). Thus, $y$ is a growing function of the difference between these two quantities: $q . r-c$.

However, under a state of ignorance, where $q$ and $r$ are not provided to individuals initially, the procedure adopted by Hogarth and Kunreuther (1995) establishes that this model should not be expected to reflect the choice behavior of individuals. Even so, Model 1 can be estimated in a state of ignorance, bearing in mind that in this study, we requested that individuals estimate $q$ and $r$ after making their choices. In this way, employing economic reasoning, the willingness to acquire insurance will increase monotonically with $q$ and $r$, and diminish with $c$.

\section{Methodology}

\section{I Research design}

Based on the arguments of Camerer and Weber (1992) and the experiments detailed by Hogarth and Kunreuther (1995), this study analyzes choice behavior within contexts of limited information regarding economically relevant variables in the decision to buy 
insurance, which is assumed in this study to be a state of ignorance. Regarding this assumption, Coombs et al. (1970) argue that states of full ignorance are rare, given that individuals have some type of information in terms of the probabilities of certain events, as well as their consequences.

\section{I. I Participants}

This study invited volunteers to participate through an advertisement published in a newspaper with a wide circulation in Brasilia, and they accepted by answering a survey, submitted to a pre-test and adjustments, composed of two blocks of questions related to their willingness to acquire extended warranties for electronic equipment. We received data for 132 people (49.2\% female), with an average age of 39.9 years and a standard deviation of 17 years, the youngest being 18 and the oldest 85 . Most of the individuals had higher education (59.1\%), with some having only primary education $(2.3 \%)$ and others having Master's degrees or PhDs (9.8\%). Almost one in three $(28.8 \%)$ had up to secondary education. Each of the 132 participants received compensation equivalent to US $\$ 12.00$, paid after they answered the second block of questions. Each block of questions corresponded to a session (called 'stage' in this study) in one of the two experiments which occurred during a given week. The participant distribution consisted of 74 individuals participating in Experiment \#1 and 58 participating in Experiment \#2.

\section{I.2 Experiments}

We used two experiments, in accordance with Hogarth and Kunreuther's procedure (1995), each one composed of two stages. Each stage occurred during a given week and there was one week between the two distinct stages. In each experiment, each stage represented the application of a group of questions related to buying an extended warranty. In Experiment \#1, the first stage occurred without the a priori availability of information about the probability of the electronic equipment breaking and its repair costs (Cell \#9 of Figure 1). After a one-week interval, the same questions were presented to the participants, but this time with the presence of information relevant to the warranty buying decision: the probability of the electronic equipment breaking and its repair costs (Cell \#1 of Figure 1). According to Hogarth

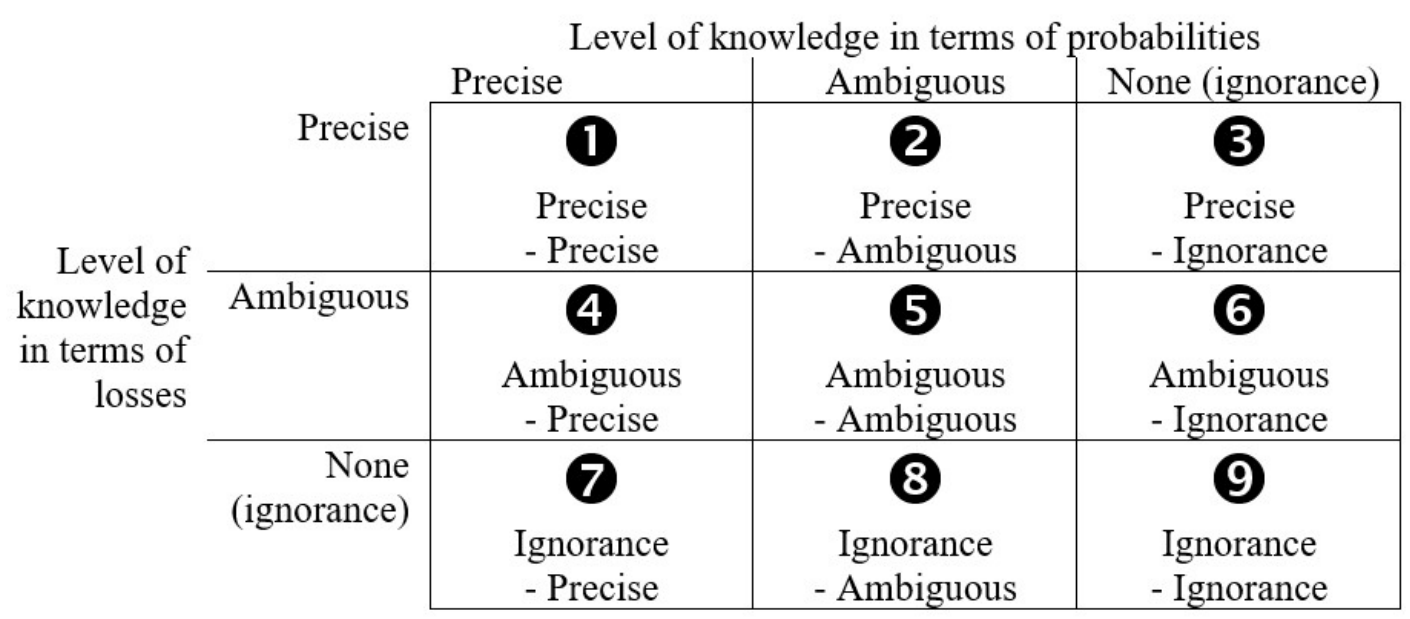

Figure 1. Characterization of Decision-Making Situations (Decision Maker Knowledge).

Note. Adapted from "Decision making under ignorance: Arguing with yourself” R. M. Hogarth \& H. Kunreuther, Journal of Risk Uncertainty, 10(1), 1995, p. 16. This figure illustrates situations in which the consumer has to make choices based on their knowledge of the probabilities of the occurrence of certain events and the potential loss involved. In Cell \#1 (context of Stage 1 of Experiment \#2 of this study) the consumer is fully informed of the probability of the occurrence of an event, as well as the loss involved if it occurs. In Cell \#9 (context of Stage 1 of Experiment \#1 of this study) represents the context of the decision maker's complete ignorance in terms of the probability of the occurrence of the event and the loss involved. 
and Kunreuther (1995), the impact of the respondent's memory is expected to be essentially null after a oneweek interval.

Experiment \#2 occurred in a similar fashion, but with the content of the stages inverted. In other words, while Experiment \#1 occurred under initial ignorance, followed by the presence of information, Experiment \#2 began with the availability of relevant information (Cell \#1 of Figure 1), which was followed after a one-week interval with no information being presented to the respondent (Cell \#9 in Figure 1). To apply the questions, a computer program was developed which made it possible to randomly present the four component scenarios of each of the two stages in each of the two experiments. Thus, in each scenario, three pieces of information were randomly selected for each respondent: i) four possibilities for equipment (TV, refrigerator, PC, or washer/dryer), ii) two possibilities for the warranty cost $(5 \%$ or $10 \%$ of the price of the equipment), and iii) two possibilities for the product's quality (good or bad). According to Rubaltelli et al. (2010), aversion to ambiguity can depend on people's emotional reactions and, therefore, the effect is more evident in comparative contexts because comparisons between clear and ambiguous alternatives lead to more positive emotional reactions in relation to the former as compared to the latter.

This study expands on previous results (Aven \& Steen, 2010; Desrochers \& Outreville, 2020; Fang, 2020; Lin et al., 2017; Hogarth \& Kunreuther, 1995) and offers additional evidence that contributes to the cumulative knowledge of the correlated literature, which constitutes a contribution to the literature as stated by Babin, Ortinau, Herrmann, and Lopez (2021), Ethiraj, Gambardell, and Helfat (2016), and Tsang and Kwan (1999).

\subsection{Data collection}

The data collection occurred during October 2015 between the first and third weeks of the month. The answers were collected in person, with the subjects located in an IT laboratory equipped with personal computers. In respect to Experiment \#1, in Scenario I the task presented to the respondents was to attribute a self-reported probability that they would buy an extended warranty for a given piece of electronic equipment, at times having and at other times lacking relevant information in terms of the probability of its breaking and the cost to repair the product. The individuals were asked: "What is the probability that you will buy the warranty?" In Scenario II the task was to assign weights to various arguments to justify their insurance purchase decision. There were 20 arguments, with 11 being in favor and nine against buying the insurance. The scale ranged from $0=$ irrelevant to $10=$ extremely important.

In Scenarios III and IV, also in Experiment \#1, we repeated the question in Scenario I with respect to other pieces of electronic equipment. At the end of Stage 1 of Experiment \#1, the individuals attributed minimum/ medium/maximum values to the probability that the equipment would break and the cost of repairing each type of equipment. In Stage 2 of Experiment \#1 (a week later) the individuals were given the same questions, but now they were provided with information about the probability of the equipment breaking and the reliability of the product (values obtained in Stage 1 of Experiment \#2), delineating a context that was no longer under ignorance, given that they had probabilities and values for repair costs to inform their decisions.

In Experiment \#2 the procedures were inverted. In Stage 1 the individuals were encouraged to indicate a response based on information regarding the probability that the equipment would break and the cost of its repair. The arguments in Scenarios III and IV were not utilized. The individuals did not make estimates of costs and probabilities at the end of the task, since they had already made these estimates at the end of Stage 1 . The cost and probability data were made available in Stage 1 of Experiment \#2, which had already been obtained in Stage 1 of the experiment.

\subsection{Empirical model for the warranty cost-benefit analysis}

According to Model 1, the decision to buy the warranty was guided by a comparison between the consumer expectations in terms of repair costs and the cost of acquiring the warranty. A way of testing the associations between the willingness to buy the warranty and the consumer's expectations in terms of the probability of the equipment breaking, the repair cost, and the cost of buying the warranty, is to conduct a regression using these variables, which is formalized in Equation 2.

$\operatorname{Pr}$ BuyingWarranty $_{i j}=\beta_{0}+\beta_{1} \operatorname{Pr}$ Breaking $_{i j}+\beta_{2}$ Repaircost $_{i j}+\beta_{3}$ Premium $_{i j}+\varepsilon_{i j}$

In addition, we will use the argument that even under a state of ignorance it is possible to estimate (2), using the information available through the level of 
knowledge of this $i$ th individual, for the $j$ th product whose warranty is being considered. In this study, in accordance with the procedure adopted by Hogarth and Kunreuther (1995), we collected this information.

\section{Results}

\section{I Intention to buy a warranty}

Tables 1 and 2 report the effects verified in Experiments \#1 and \#2 (in both stages) in terms of the reported probability that the consumer would buy an extended warranty for the following pieces of electronic equipment: refrigerator, television, washer/dryer, and a personal computer (PC) of the all-in-one type.

For this phase of analysis, each product was treated separately. In accordance with Tabachnick and Fidell (2007), we conducted an Analysis of Variance (ANOVA) with a single within-subject factor (Stage \#1 vs. Stage \#2, in each of the two experiments conducted), to test the null hypothesis that there is no difference between the probabilities of buying insurance in Stage 1

Table 1

Experiment \#1 - Probability of Buying Reported by the Consumer

\begin{tabular}{|c|c|c|c|c|c|c|c|}
\hline \multirow{3}{*}{ Equipment } & \multirow{3}{*}{ Price $^{(\mathrm{a})}$} & \multicolumn{3}{|c|}{ Stage \#1 (Ignorance) } & \multicolumn{3}{|c|}{ Stage \#2 (Risk) } \\
\hline & & \multicolumn{3}{|c|}{ Product reliability } & \multicolumn{3}{|c|}{ Product reliability } \\
\hline & & Low & & High & Low & & High \\
\hline \multirow[t]{3}{*}{ Refrigerator $(N=64)$} & $5 \%$ & 46.91 & & 50.00 & 44.55 & & 53.33 \\
\hline & $10 \%$ & 39.21 & & 25.00 & 35.56 & & 35.00 \\
\hline & & & $42.12^{\dagger}$ & & & $42.10^{\dagger}$ & \\
\hline \multirow[t]{3}{*}{ Television $(\mathrm{N}=53)$} & $5 \%$ & 40.00 & & 31.00 & 41.67 & & 20.00 \\
\hline & $10 \%$ & 48.75 & & 24.29 & 41.09 & & 40.45 \\
\hline & & & $33.71^{\dagger}$ & & & $38.30^{\dagger}$ & \\
\hline \multirow{3}{*}{ Washer Dryer $(\mathrm{N}=66)$} & $5 \%$ & 57.92 & & 43.57 & 50.00 & & 44.17 \\
\hline & $10 \%$ & 41.35 & & 25.78 & 37.27 & & 35.89 \\
\hline & & & $39.41^{\dagger}$ & & & $40.91^{\dagger}$ & \\
\hline \multirow[t]{3}{*}{$\mathrm{PC}(\mathrm{N}=66)$} & $5 \%$ & 57.50 & & 41.29 & 63.33 & & 39.17 \\
\hline & $10 \%$ & 34.55 & & 28.85 & 43.64 & & 25.00 \\
\hline & & & $39.02^{\dagger}$ & & & $39.32^{\dagger}$ & \\
\hline
\end{tabular}

Note. Calculations by the authors based on the collected data. ${ }^{(a)}$ Premium to be paid (cost of the insurance) for an extended warranty.

${ }^{\dagger}$ Average of the willingness to buy an extended warranty per piece of equipment.

Table 2

\section{Experiment \#2 - Probability of Buying Reported by the Consumer}

\begin{tabular}{|c|c|c|c|c|c|c|c|}
\hline \multirow{3}{*}{ Equipment } & \multirow{3}{*}{ Price $^{(a)}$} & \multicolumn{3}{|c|}{ Stage \# 1 (Risk) } & \multicolumn{3}{|c|}{ Stage \#2 (Ignorance) } \\
\hline & & \multicolumn{3}{|c|}{ Product reliability } & \multicolumn{3}{|c|}{ Product reliability } \\
\hline & & Low & & High & Low & & High \\
\hline \multirow[t]{3}{*}{ Refrigerator $(\mathrm{N}=46)$} & $5 \%$ & 36.67 & & 19.75 & 44.52 & & 48.33 \\
\hline & $10 \%$ & 32.92 & & 11.00 & 45.35 & & 32.60 \\
\hline & & & $33.02^{\dagger}$ & & & $43.78^{\dagger}$ & \\
\hline \multirow[t]{3}{*}{ Television $(\mathrm{N}=43)$} & $5 \%$ & 44.32 & & 31.83 & 43.57 & & 40.70 \\
\hline & $10 \%$ & 46.82 & & 45.89 & 37.94 & & 33.33 \\
\hline & & & $41.80^{\dagger}$ & & & $39.41^{\dagger}$ & \\
\hline \multirow{3}{*}{ Washer Dryer ( $\mathrm{N}=48)$} & $5 \%$ & 46.75 & & 36.15 & 38.23 & & 32.33 \\
\hline & $10 \%$ & 34.80 & & 32.38 & 46.63 & & 32.78 \\
\hline & & & $36.89^{\dagger}$ & & & $36.47^{\dagger}$ & \\
\hline \multirow[t]{3}{*}{$\mathrm{PC}(\mathrm{N}=47)$} & $5 \%$ & 55.67 & & 35.19 & 50.00 & & 35.64 \\
\hline & $10 \%$ & 32.00 & & 47.42 & 30.20 & & 30.00 \\
\hline & & & $39.27^{\dagger}$ & & & $33.75^{\dagger}$ & \\
\hline
\end{tabular}

Note. Calculations by the authors based on the collected data. ${ }^{(a)}$ Premium to be paid (cost of the insurance) for an extended warranty. ${ }^{\dagger}$ Average of the willingness to buy an extended warranty per piece of equipment. 
and Stage 2. The ANOVA results indicate that there is no significance that can be attributed to the availability of information about the extended warranty for all of the electronic equipment in the two experiments. For example, for the refrigerator $(\mathrm{N}=64)$ in Experiment \#1, $F$ (1.63) $=0.686$; $\mathrm{p}$-value $>0.1$; and $\eta^{2}=0.012$.

Thus, there was no significant difference between the probability of buying an extended warranty for the refrigerator (as with the other electronic equipment) between the two Stages \#1 and \#2 of Experiment \#1, as was true for all of the equipment considered in Experiment \#2. This result suggests that the availability of information related to the probability of the refrigerator breaking (as with the other electronic equipment), appears to not have influenced the propensity of the respondents to buy an extended warranty, when we consider the group of people who responded initially in a state of ignorance, i.e. Experiment \#1.

Even though the conducted tests did not indicate significant differences between Stages 1 and 2 in the two experiments, it appears to be relevant to verify the values found within each context of the decisions presented to the respondents. Thus, observing Table 1 , among the values verified in terms of the propensity to buy an extended warranty, in Stage 1 (under a state of ignorance) for the $\mathrm{TV}$, it appears that the propensity to buy a warranty is greater when the reliability of the equipment is considered to be low. Something similar appears to occur with the washer dryer and the personal computer.

And, observing the results reported in Table 2, it appears that this finding is generally repeated within a context of risk, i.e. even though there are data available about the probability of it breaking and its repair costs, if the reliability of the product is lower, the consumer appears to be more willing to buy an extended warranty. Keeping in mind the limitations of the data in this study, future research can concentrate on conducting investigations using tests such as Two-Way ANOVA to verify the influence of the price of a warranty and the reliability of the equipment when there are a greater number of observations for each context.

\subsection{Cost-benefit analysis of the warranty}

In terms of empirical Model 2, in accordance with Hogarth and Kunreuther (1995), under conditions with full restriction of relevant information (probability of breaking and the cost of repairs) or ignorance (Cell
\#9), it is expected that the behavior of individuals will be different when they have/do not have information to make their decision. Table 3 displays the results for the $t$ statistics found in the regressions, where the dependent variable is the willingness to buy a warranty, as a function of the cost of repairing each piece of electronic equipment, the probability of the equipment breaking, and the cost of the warranty (premium).

For each of the two stages in each one of the experiments, we conducted a regression, considering the responses collected for each piece of equipment separately. Panel A of Table 3 shows the results of the regressions related to Experiment \#1, and from the $F$ statistic, we can see that all of the models were significant, whether they were under conditions of ignorance or under risk. In Experiment \#2, reported in Panel B, only the results obtained for the inox refrigerator as well as the results for the $10 \mathrm{~kg}$ washer dryer in Stage 2 (ignorance) were significant.

If we consider the eight decision contexts under ignorance, the models are significant in six of them, including all four in Experiment \#1, and two of the four in Experiment \#2. And, if we observe the results obtained for the repair cost of the equipment, for seven of the eight situations in Experiment \#1, the results were significant and indicate a positive association between repair cost and propensity to buy an extended warranty.

In Experiment \#2, when the information regarding the probability of breaking and the repair cost is supplied a priori, the cost of insurance was not significant in any of the eight situations relative to the four electronic items. On the contrary, in Experiment \#1, in which the information is not provided a priori, the cost of insurance was significant in three of the four situations (only the 3D HD TV was not significant; $p$-value $>0.1$ ).

This result is, at least in part, different from that obtained by Hogarth and Kunreuther (1995), who found a negative association with the cost of insurance, but only in Experiment \#2, and for both stages (ignorance and risk) for a single piece of equipment. Or in other words, according to these findings, there are indications that suggest that the absence of relevant information makes the cost of insurance relevant and negatively associated with the willingness to buy an extended warranty. Expressed in another way, the premium paid for the warranty, in the presence of information about the probability of the equipment breaking and the cost of repairs, does not 
Table 3

Regressions for the Propensity to Buy a Warranty

\begin{tabular}{|c|c|c|c|c|c|c|c|c|c|}
\hline \multicolumn{10}{|c|}{$\operatorname{Pr}$ BuyingWarranty $_{i j}=\beta_{0}+\beta_{1} \operatorname{Pr}$ Breaking $_{i j}+\beta_{2}$ Repair Cost $_{i j}+\beta_{3}$ Premium $_{i j}+\varepsilon_{i j}$} \\
\hline & \multirow[b]{2}{*}{ Stage } & \multicolumn{6}{|c|}{ t statistic } & \multirow[b]{2}{*}{$\mathbf{R}^{2}$} & \multirow[b]{2}{*}{$\mathbf{F}$} \\
\hline & & $\begin{array}{c}\text { Repair } \\
\text { Cost }\end{array}$ & & $\begin{array}{c}\text { Probability of } \\
\text { Breaking } \\
\end{array}$ & & $\begin{array}{c}\text { Cost of } \\
\text { Insurance }\end{array}$ & & & \\
\hline \multicolumn{10}{|c|}{ Panel A: Experiment \#1 } \\
\hline \multirow[t]{2}{*}{ Refrigerator } & Stage 1 (Ignorance) & 2.78 & $* * *$ & 0.68 & & -1.92 & * & 0.116 & $* *$ \\
\hline & Stage 2 (Risk) & 1.72 & $*$ & 2.68 & $* *$ & -1.57 & & 0.212 & $* *$ \\
\hline \multirow[t]{2}{*}{ TV } & Stage 1 (Ignorance) & 3.85 & $* * *$ & 3.26 & $* * *$ & -0.81 & & 0.402 & $* * *$ \\
\hline & Stage 2 (Risk) & 2.77 & $* * *$ & 4.49 & $* * *$ & 0.02 & & 0.327 & $* * *$ \\
\hline \multirow[t]{2}{*}{ Washer Dryer } & Stage 1 (Ignorance) & 1.52 & & 1.57 & & -1.94 & * & 0.129 & $* * *$ \\
\hline & Stage 2 (Risk) & 2.02 & $* *$ & 4.83 & $* * *$ & -0.16 & & 0.384 & $* * *$ \\
\hline \multirow[t]{2}{*}{ PC } & Stage 1 (Ignorance) & 2.40 & $* *$ & 0.87 & & -1.92 & * & 0.095 & ** \\
\hline & Stage 2 (Risk) & 2.23 & $* *$ & 3.98 & $* * *$ & -1.62 & & 0.235 & $* * *$ \\
\hline \multicolumn{10}{|c|}{ Panel B: Experiment \#2 } \\
\hline \multirow[t]{2}{*}{ Refrigerator } & Stage 1 (Risk) & 2.53 & $* *$ & -0.98 & & 0.50 & & 0.095 & $*$ \\
\hline & Stage 2 (Ignorance) & 2.24 & $* *$ & 2.58 & $* *$ & -0.90 & & 0.209 & $* * *$ \\
\hline \multirow[t]{2}{*}{ TV } & Stage 1 (Risk) & -0.22 & & 0.25 & & 0.63 & & -0.056 & \\
\hline & Stage 2 (Ignorance) & 0.71 & & 1.58 & & -0.63 & & -0.005 & \\
\hline \multirow[t]{2}{*}{ Washer Dryer } & Stage 1 (Risk) & 1.95 & $*$ & 0.81 & & -1.04 & & 0.036 & \\
\hline & Stage 2 (Ignorance) & 1.44 & & 2.51 & $* *$ & 0.46 & & 0.101 & $*$ \\
\hline \multirow[t]{2}{*}{ PC } & Stage 1 (Risk) & 0.94 & & 0.54 & & 0.81 & & -0.034 & \\
\hline & Stage 2 (Ignorance) & 0.08 & & 2.00 & $*$ & -1.01 & & 0.039 & \\
\hline
\end{tabular}

Note. Calculations made by the authors based on the collected data. ${ }^{* *} \mathrm{p}$-value $<0.01 ;{ }^{\star *} \mathrm{p}$-value $<0.05 ;{ }^{\star} \mathrm{p}$-value $<0.1$.

appear to play a significant role in the willingness of the consumer to buy an extended warranty.

\subsection{Arguments employed in buying decisions}

In respect to motivations for buying insurance, that is, the particular types of arguments employed by consumers to justify their buying decisions, we verified the scores attributed to the arguments provided a priori (Table 4). To accomplish this, we verified 20 different types of arguments, with 11 being arguments to buy an extended warranty and nine being arguments not to buy one, in accordance with the list of arguments suggested by Hogarth and Kunreuther (1995). These arguments were presented to the participants after making their choices in the second scenario of each stage of the experiments.

In addition, these 20 arguments are organized into two subgroups of meta and non-meta arguments for and against buying the extended warranty. Our intention in adopting this classification is based on the idea that people frequently use arguments to justify their buying decisions to the detriment of processing relevant economic information.

In this respect, it is understood that there are arguments against and in favor of buying the extended warranty. For example, under conditions of risk: the 'probability of breaking' may be associated with the decision not to buy the warranty, and the 'cost of insurance' and the 'repair costs' can also motivate the decision not to buy the warranty. The literature suggests that decisions made by individuals are frequently supported by specific rules or strategies. Two general types of decision-making strategies are common: meta strategies and non-meta strategies. In operational terms, it is understood that metastrategies essentially consist of rules to resolve problems, such as regret: 'I would regret not buying the warranty if the equipment were to break'; or a principle adopted by individuals in these types of situations: 'I never buy this type of warranty.'

On the other hand, non-meta strategies are more responsive to the details that stimulate the decision, such as expressions of the type 'The repair costs are less than $\mathrm{R} \$ 200.00$, but the cost of the warranty is more than $\mathrm{R} \$ 1,000$.' It is possible to state that there are no 
Table 4

Average Scores Found for Arguments Shown to the Respondents

\begin{tabular}{|c|c|c|c|c|}
\hline \multirow{2}{*}{ Arguments } & \multicolumn{2}{|c|}{ Experiment \#1 } & \multicolumn{2}{|c|}{ Experiment \#2 } \\
\hline & Ignorance & Risk & Ignorance & Risk \\
\hline \multicolumn{5}{|l|}{ Panel A: Reasons to buy a warranty } \\
\hline \multicolumn{5}{|l|}{ Meta-arguments: } \\
\hline I usually buy these types of warranties & 3.03 & 2.81 & 3.40 & 3.24 \\
\hline I would regret not having bought the warranty if the equipment were to break & 6.38 & 5.61 & 5.19 & 4.90 \\
\hline I would sleep better if I had the warranty & 4.08 & 3.84 & 5.45 & 3.59 \\
\hline I am unlucky. My products always break & 2.53 & 2.84 & 2.34 & 2.71 \\
\hline \multicolumn{5}{|l|}{ Non-meta-arguments: } \\
\hline The cost of the warranty is relatively low compared to the product's price & 5.26 & 5.42 & 4.66 & 4.74 \\
\hline The cost of repairing (or exchanging) would be much greater than the cost of the warranty & 6.39 & 6.32 & 7.50 & 6.07 \\
\hline The warranty is not expensive & 5.27 & 5.55 & 4.40 & 4.90 \\
\hline This type of product breaks easily & 5.12 & 5.12 & 4.16 & $5.19^{* *}$ \\
\hline Even though the risk of a loss appears low, I don't want to be responsible for it & 4.91 & 4.36 & 3.79 & 3.98 \\
\hline The cost of the warranty is not high compared to the chance of something going wrong & 5.86 & 5.89 & 4.71 & $5.59^{*}$ \\
\hline This product is very valuable to me & 6.08 & 6.53 & 6.17 & 6.05 \\
\hline \multicolumn{5}{|l|}{ Panel B: Reasons to not buy a warranty } \\
\hline \multicolumn{5}{|l|}{ Meta-arguments: } \\
\hline I am lucky. My electronic equipment does not break & 4.30 & 4.08 & 4.62 & 3.76 \\
\hline $\begin{array}{l}\text { I do not believe in insurance and warranties. They do not always cover everything and there } \\
\text { is a lot of bureaucracy }\end{array}$ & 5.55 & 5.46 & 4.86 & 4.79 \\
\hline I usually do not buy warranties of this type & 5.30 & 5.19 & 5.45 & 5.31 \\
\hline I would regret spending money to buy a warranty if the equipment did not break & 6.07 & 5.61 & 5.66 & 5.53 \\
\hline \multicolumn{5}{|l|}{ Non-meta-arguments: } \\
\hline The product is a type that rarely breaks & 7.12 & 7.07 & 5.62 & 5.81 \\
\hline The warranty is expensive compared to the product's price & 6.31 & 6.38 & 5.43 & 5.84 \\
\hline This product is not that valuable to me & 5.73 & 5.81 & 3.95 & 4.60 \\
\hline The cost of the warranty is high compared to the chance of something going wrong & 6.53 & 6.42 & 5.41 & 6.05 \\
\hline The warranty's price is high & 6.80 & 6.70 & 5.71 & 6.40 \\
\hline
\end{tabular}

Note. Calculations by the authors based on the collected data. ${ }^{* *}$ p-value $<0.05 ;{ }^{*}$ p-value $<0.1$.

significant differences between the scores attributed to the arguments within contexts of ignorance or risk in Experiment \#1. In Experiment \#2, two arguments present significant differences in weight between Stage 1 (risk) and Stage 2 (ignorance).

The argument 'This type of product breaks easily' received the greatest weight under risk, compared to ignorance (5.19 versus $4.16 ; t=2.00 ; \mathrm{p}$-value $<0.05$ ). This result suggests the sensitivity of the consumer to the expectation that the product may break when deciding whether to buy an extended warranty. The other argument in Experiment \#2 which presented a significant difference between the two stages was 'The cost of the warranty is not high compared to the chance of something going wrong,' which received greater weight within the context of risk (5.59 versus $4.71 ; t=1.98$; $\mathrm{p}$-value $<0.1$ ).

\section{Final Considerations and Implications}

This study follows suggestions made by field studies about decision making under ignorance, as indicated by Burke and Fry (2019), Fichera and von Hinke (2020), and Loewenstein et al. (2014). The subject of choice under risk has been studied based on the assumption that decision makers are fully informed. However, in real life situations, individuals frequently need to make choices while lacking essential information for making their judgements. Thus, this study focuses on the analysis of decision making under conditions with an absence of information about the probabilities of losses and potential impacts, a context of ignorance, or alternatively contexts of risk or uncertainty. 
Based on Hogarth and Kunreuther's procedure (1995) and based on data collected from two experiments regarding the propensity of acquiring extended warranties for electronic equipment, featuring the participation of more than 130 people, our results suggest that the repair cost and the probability that a piece of equipment will break increase the propensity to buy extended warranties. In addition, the absence of economic information makes the cost of insurance relevant, and it is negatively associated with the propensity to buy an extended warranty.

The implications of this study can be enunciated based on three aspects: descriptive, normative, and prescriptive. In descriptive terms, this study offers evidence of the behavior of individuals when making decisions whether to buy an extended warranty. In normative terms, this study reviews and discusses the theoretical fundamentals related to ignorance when making decisions about buying insurance.

In respect to the prescriptive implications, based on the empirical evidence found as it interacts with the discussed theoretical fundamentals, it is understood that works similar to this one may be relevant to the formation of public policies related to the regulation of product disclosure, above all for financial products, and also in the corporate world for financial firms (that offer financial products designed to protect consumers), and non-financial firms (which sell physical products that offer warranties).

We suggest expanding the line of research pursued here to include emerging subjects such as the consumption of financial products dedicated to protecting against extreme events due to climate change (Kunreuther et al., 2013a, 2013b). In this respect, it is understood that investigating differences in risk aversion through demographic profiles may be a relevant research agenda in seeking new results and counterfactual evidence in the field of risk aversion, as argued by Campbell (2020), Gunewardena and Seck (2020), and Nelson (2015).

Above all, less developed markets, in which access to relevant information tends to be reduced, present a contribution to integral consumer information about the probability of equipment failure and the possibility of buying warranties, because if they are not in possession of precise information, the individual will inevitably make decisions based on heuristics and non-economic motivations.

The behavioral finance literature has documented that people tend to present behavior characterized by inertia and procrastination, maintaining the status quo. And, in this respect, new technologies like the IoT can play a relevant role in that they assume this tendency in human behavior, offering consumers information without depending on their having active attitudes.

In other words, emerging technologies, such as the IoT, associated with the actions of policy makers, can be central to raising the efficiency of the consumer market, making relevant information accessible for consumption decisions such as for credit cards, cell phone plans, and real estate financing, in as transparent and efficient a manner as for buying plane tickets. The surge in search engines has assisted consumers, making the market more efficient, and improving the way in which governments serve their citizens (Thaler \& Tucker, 2013).

As it deals with financial products, the insurance market needs more studies concerning the supply side of products, as well as the consumer, because knowledge related to the participants in this market may be crucial to its growth around the world, especially in emerging markets. The extended warranty market in Brazil represented around 2\% of the insurance market in Brazil in 2013 (an estimated $\mathrm{R} \$ 201,974,716,000$ in 2014, with $13.5 \%$ growth), in which the largest segments were retirement plans (42.8\%) and automobiles (20.2\%), according to statistics from SUSEP (2014).

In terms of the empirical results and the characteristics of the data, we must recognize that the empirical results are conditioned by the profile of the data. Therefore, parsimony should be used in generalizing the results. In contrast to this limitation, a research agenda presents itself in that the limitations of the data may constitute a motive for new studies. In summary, this economic phenomenon has shown itself to be relevant and worthy of new studies, and the results documented here reveal the role that information can play in consumption decisions regarding financial services, which may be conditioned by the consumer's profile and other contextual aspects of the decision.

The theoretical questions reported in this study regarding decisions made under ignorance can be added to the arguments found in the finance literature, which suggest the potential of the finance industry based on knowledge of individual behavior when dealing with the insurance market (and various submarkets) and suggest the existence of a research agenda which may attract the attention of the finance community (Zeckhauser, 2014). 


\section{References}

AGARWAL, S., CHOMSISENGPHET, S., LIU, C., \& SOULELES, N. S. (2015). Do consumers choose the right credit contracts? Review of Corporate Finance Studies, 4(2), 239-257. https://doi.org/10.1093/rcfs/cfv003

ARROW, K. J. (1965). Aspects of the theory of risk bearing. Academic Publishers.

ARROW, K. J., \& HURWICZ, L. (1977). An optimality criterion for decision making under ignorance, in K.J. Arrow, L. Hurwicz (Eds.) Studies in Resource Allocation Process (pp. pp. 393-460). Cambridge: University Press.

AVEN, T., STEEN, R. (2010). The concept of ignorance in a risk assessment and management context. Reliability Engineering \& System Safety, 95(11), 1117-1122. https:// doi.org/10.1016/j.ress.2010.05.006

BABIN, B. J., ORTINAU, D. J., HERRMANN, J. L., \& LOPEZ, C. (2021). Science is about corroborating empirical evidence, even in academic business research journals. Journal of Business Research, 126, 504-511. https://doi.org/10.1016/j.jbusres.2020.06.002

BANKS, J., BASSOLI, E., \& MAMMI, I. (2019). Changing attitudes to risk at older ages: The role of health and other life events. Journal of Economic Psychology, 79, 1-20. https://doi.org/10.1016/j.joep.2019.102208

BENÍTEZ, J., CARPITELLA S., CERTA A., \& IZQUIERDO J. (2019). Management of uncertain pairwise comparisons in AHP through probabilistic concepts. Applied Soft Computing Journal, 78, 274-285. https://doi.org/10.1016/j.asoc.2019.02.020

BEN-SHAHAR, O., \& SCHNEIDER, C. E. (2011). The failure of mandated disclosure. University of Pennsylvania Law Review, 159, 687-90. Retrieved from https://www. law.upenn.edu/journals/lawreview/articles/volume159/ issue3/BenShaharSchneider159U.Pa.L.Rev.647(2011).pdf

BERTRAND, M., \& MORSE, A. (2011). Information disclosure, cognitive biases, and payday borrowing, Journal of Finance, 66(6), 1865-1893. https://doi.org/10.1111/ j.1540-6261.2011.01698.x

BROWN, J. R., KLING, J. R., MULLAINATHAN, S., \& WROBEL, M. V. (2008). Why don't people insure late-life consumption? A framing explanation of the under-annuitization puzzle. American Economic Review, 98(2), 304-309. https://www.aeaweb.org/articles/pdf/ doi/10.1257/aer.98.2.304

BURKE, M., \& FRY, J. (2019). How easy is it to understand consumer finance? Economics Letters, 177, 1-4. https:// doi.org/10.1016/j.econlet.2019.01.004

CABANTOUS, L., HILTON, D., KUNREUTHER, H., \& MICHEL-KERJAN, E. (2011). Is imprecise knowledge better than conflicting expertise? Evidence from insurers' decisions in the United States. Journal of Risk Uncertainty, 42(3), 243-254. Doi: 10.1007/s11166011-9117-1

CAMERER, C. F., \& WEBER, M. (1992). Recent developments in modeling preferences: Uncertainty and ambiguity. Journal of Risk Uncertainty, 5(4), 115-147. https://www.jstor.org/stable/41755006

CAMPBELL, A. (2020). Survival, selection, and sex differences in fear. The Cambridge Handbook of Evolutionary Perspectives on Human Behavior, 313-329. https://doi. org/10.1017/9781108131797.027

COOMBS, C.H., DAWES, R. M., \& TVERSKY, A. (1970). Mathematical psychology: An Elementary introduction, Englewoods Cliffs, NJ: Prentice Hall.

DESROCHERS, J., \& OUTREVILLE, J. F. (2020). Perceived risk and insurance decision taking for small losses. Journal of Risk Research, 23(4), 447-460. https:// doi.org/10.1080/13669877.2019.1591485

DIACON, S., \& HASSELDINE, J. (2007). Framing effects and risk perception: The effect of prior performance presentation format on investment fund choice. Journal of Economic Psychology, 28(1), 31-52. https://doi.org/10.1016/j. joep.2006.01.003

DIN, S. M. U., ABU-BAKAR, A., \& REGUPATHI, A. (2017). Does insurance promote economic growth: A comparative study of developed and emerging/developing economies. Cogent Economics \& Finance, 5(1), 1-13. https://doi.org/10.1080/23322039.2017.1390029

ELLSBERG, D. (1961). Risk, ambiguity, and the savage axioms. The Quarterly Journal of Economics, 75(4), 643669. https://doi.org/10.2307/1884324 
ETHIRAJ, S., GAMBARDELLA, A., \& HELFAT, C. (2016). Replication in strategic management. Strategic Management Journal, 37(11), 2191-2192. https:/doi. org/10.1002/smj.2581

FANG, C. C. (2020). Optimal price and warranty decision for durable products in a competitive duopoly market. Reliability Engineering and System Safety, 203, 1-15. https://doi.org/10.1016/j.ress.2020.107068

FICHERA, E., \& VON HINKE, S. (2020). The response to nutritional labels: Evidence from a quasi-experiment. Journal of Health Economics, 72, 1-17. https://doi. org/10.1016/j.jhealeco.2020.102326

GIANG, P. H. (2015). Decision making under uncertainty comprising complete ignorance and probability. International Journal of Approximate Reasoning, 62(1), 27-45. https:// doi.org/10.1016/j.ijar.2015.05.001

GUNEWARDENA, D., \& SECK, A. (2020). Heterogeneity in entrepreneurship in developing countries: Risk, credit, and migration and the entrepreneurial propensity of youth and women. Review of Development Economics, 24 (3), 713-725. https://doi.org/10.1111/rode.12703

HASTINGS, J. S., \& TEJEDA-ASHTON, L. (2008). Financial literacy, information, and demand elasticity: Survey and experimental evidence from Mexico, (NBER Working Paper No.14538). Retrieved from: https://www. nber.org/papers/w14538

Health \& Safety Executive. (2001). Reducing risks, protecting people: HSE's decision making process, HSE Books. Retrieved from: http://www.hse.gov.uk/risk/theory/r2p2.pdf

HOGARTH, R. M., \& KUNREUTHER, H. (1995). Decision Making under Ignorance: Arguing with Yourself. Journal of Risk Uncertainty, 10(1), 15-36. Doi: 10.1007/978-3-319-22527-2_20

HOGATH, J. M., \& MERRY, E. A. (2011). Designing disclosures to inform consumer financial decision-making: Lessons learned from consumer testing. Federal Reserve Bulletin. Retrieved from: http://EconPapers.repec.org/ RePEc:fip:fedgrb:y:2011:i:august:n:v.97

HOWLETT, E., \& PAGANO, M. (2008). The effects of summary information on consumer perceptions of mutual fund characteristics. Journal of Consumer Affairs, 42(1), 37-59. https://doi.org/10.1111/j.1745-6606.2007.00093.x

JINDAL, P. (2015). Risk preferences and demand drivers of extended warranties. Marketing Science, 34(1), 39-58. https://doi.org/10.1287/mksc.2014.0879

JONES, L. E., LOIBL, C., \& TENNYSON, S. (2015). Effects of informational nudges on consumer debt repayment behaviors. Journal of Economic Psychology, 51(1), 16-33. https://doi.org/10.1016/j.joep.2015.06.009

KLEINDORFER, P.R., KUNREUTHER, H.C., \& SCHOEMAKER, P.J.H. (1993). Decision Sciences: An Integrated Approach, New York: Cambridge University Press.

KNIGHT, F. H. (1921). Risk, uncertainty and profit. Boston: Houghton Mifflin Company.

KUNREUTHER, H. C., HEAL, G., ALlEN, M., EDENHOFER, O., FIELD, C. B., \& YOHE, G. (2013a). Risk management and climate change. Nature Climate Change, 3(5), 447-450. Retrieved from: https:// www.nature.com/articles/nclimate1740

KUNREUTHER, H. C., PAULY, M. V., \& MCMORROW, S. (2013b). Insurance \& behavioral economics: Improving decisions in the most misunderstood industry. New York: Cambridge University Press.

LAIBSON, D. (1997). Golden eggs and hyperbolic discounting. Quarterly Journal of Economics, 112(2), 443-78. https://doi.org/10.1162/003355397555253

LAURA, D. S., MIHAI, D. C., \& MIHAELA, M. G. (2020). From intention to decision in purchasing life insurance and private pensions: Different effects of knowledge and behavioural factors. Journal of Behavioral and Experimental Economics, 87, 1-19. https://doi. org/10.1016/j.socec.2020.101555

LIN, C., HSIAO, Y. J., \& YEH, C. Y. (2017). Financial literacy, financial advisors, and information sources on demand for life insurance. Pacific-Basin Finance Journal, 43, 218 237. https://doi.org/10.1016/j.pacfin.2017.04.002

LOEWENSTEIN, G., SUNSTEIN, C. R., \& GOLMAN, R. (2014). Disclosure: Psychology changes everything. Annual Review of Economics, 6, 391-419. https://www. 
annualreviews.org/doi/abs/10.1146/annurev-economics080213-041341 ?journalCode=economics

MASKIN, E. (1979). Decision-making under ignorance with implications for social choice. Theory and Decision, 11(3), 319-337. Retrieved from: https://link.springer. com/chapter/10.1007/978-94-009-9532-1_9

MUMO, R., WATT, R. (2019). Residential insurance market responses after earthquake: A survey of Christchurch dwellers. International Journal of Disaster Risk Reduction, 40, 1-6. https://doi.org/10.1016/j.ijdrr.2019.101166

NELSON, J. A. (2015). Are women really more risk-averse than men? A re-analysis of the literature using expanded methods, Journal of Economic Surveys, 29(3), 566-585.

OECD (2008). Promoting sustainable consumption: Good practices in PECD countries. Retrieved from: http://www. oecd.org/greengrowth/40317373.pdf

Office of Fair Trading (2010). What does Behavioural Economics mean for Competition Policy? OFT\#1224. Retrieved from: http://webarchive.nationalarchives.gov. uk/20140402142426/http:/www.oft.gov.uk/shared_oft/ economic_research/oft1224.pdf

OUTREVILLE, J. F. (2014). Risk aversion, risk behavior, and demand for insurance: A Survey. Journal of Insurance Issue, 37(2), 158-186. https://www.jstor.org/stable/43151298

Oxera (2014). Review of literature on product disclosure. Retrieved from: https://www.fca.org.uk/your-fca/documents/ research/review-of-literature-on-product-disclosure.

PRATT, J. W. (1964). Risk aversion in the small and large. Econometrica, 32(1/2), 122-136. https://doi.org/10.1016/ B978-0-12-214850-7.50010-3

ROBB, C. A., BABIARZ, P., WOODYARD, A., \& SEAY, M. C. (2015). Bounded Rationality and Use of Alternative Financial Services. Journal of Consumer Affairs, 49(2), 407-435. https://doi.org/10.1111/joca.12071

RUBALTELLI, E., RUMIATI, R., \& SLOVIC, P. (2010). Do ambiguity avoidance and comparative ignorance hypothesis depend on people's affective reactions? Journal of Risk Uncertainty, 40(3), 243-254. https://link.springer. com/article/10.1007/s11166-010-9091-z
SICHERMAN, N., LOEWENSTEIN, G., SEPPI, D., \& UTKUS, S. (2016). Financial attention. Review of Financial Studies, 29(4), 863-897. https://doi.org/10.1093/ rfs/hhv073

SOKOLOWSKA, J., \& ZALESKIEWICZ, T. (2020). Willingness to bear economic costs in the fight against COVID-19 pandemic. Frontiers in Psychology, 11. https:// doi.org/10.3389/fpsyg.2020.588910

SUSEP (2014). Superintendência de Seguros Privados. Stolen Car Index (Índice de Carros Roubados). Retrieved from www.susep.gov.br

TABACHNICK, B. G., \& FIDELL, L. S. (2007). Using multivariate statistics (5th ed.). New York: Pearson.

TCHIEHE, D. N., \& GAUTHIER, F. (2017). Classification of risk acceptability and risk tolerability factors in occupational health and safety. Safety Science, 92(1). 138-147. https://doi.org/10.1016/j.ssci.2016.10.003

THALER, R. H., \& TUCKER, W. (2013). Smarter information, smarter consumers, Harvard Business Review. https://doi.org/10.1016/j.jbusres.2018.12.036

TSANG, E. W., \& KWAN, K. M. (1999). Replication and theory development in organizational science: A critical realist perspective. Academy of Management Review, 24(4), 759-780. https://doi.org/10.5465/amr.1999.2553252

WOODWARD, S. E., \& HALL, R. E. (2010). Consumer confusion in the mortgage market: Evidence of less than a perfectly transparent and competitive market. The American Economic Review, 100(2), 511-515. https:// www.jstor.org/stable/27805049

World Economic Forum (2012). Rethinking Personal Data: Strengthening Trust. Retrieved from: http://www3. weforum.org/docs/WEF_IT_RethinkingPersonalData_ Report_2012.pdf.

ZECKHAUSER, R. (2014). New frontiers beyond risk and uncertainty: Ignorance, group decision, and unanticipated themes. In W.K. Viscusi \& M. Machina (Eds.). Handbook of the Economics of Risk and Uncertainty (pp. xvii-xxix), Oxford: Elsevier. 


\section{Financial support:}

The authors are grateful for and acknowledge the financial and institutional support of The IC ${ }^{2}$ Institute of The University of Texas and two agencies that made possible the work related to this research: The National Council for Scientific and Technological Development-CNPq (Grants \# 309227/2019-4 and \#40920520168) and The São Paulo Research Foundation-FAPESP (Grant \#14/26003-9). The first author also thanks the Fundação Getulio Vargas (FGV) for the financial support and infrastructure that allowed this research to be carried out.

\section{Open Science}

Data disclosure: The data and questionnaire used in this research are publicly available, in line with the RBGN's Open Science policy at: Mendes-Da-Silva, Wesley. (2021). Data for replication of article 'Decisão sob Ignorância e Disclosure de Produto: Implicaçóes na Compra de Seguros'. [Data set]. Revista Brasileira de Gestão de Negócios. Zenodo. http://doi. org/10.5281/zenodo.4699512.

\section{Conflicts of interest:}

The authors have no conflict of interest to declare.

\section{Copyrights:}

RBGN owns the copyrights of this published content.

\section{Plagiarism analysis:}

RBGN performs plagiarism analysis on all its articles at the time of submission and after approval of the manuscript using the iThenticate tool.

\section{Authors:}

1. Wesley Mendes-Da-Silva, Associate Professor, Escola de Administração de Empresas de São Paulo da Fundação Getulio Vargas (FGV/EAESP), São Paulo, Brazil. mr.mendesdasilva@gmail.com.

2. Cristiane C. Gattaz, Researcher Affiliated with the IC ${ }^{2}$ Institute, University of Texas at Austin, Austin, United States. cristiane.gattaz@utexas.edu.

3. David V. Gibson, Full Professor, University of Texas at Austin, Austin, United States. davidg@ic2.utexas.edu.

\section{Authors' Contributions:}

Wesley Mendes-Da-Silva: Definition of research problem; Development of hypotheses or research questions (empirical studies); Definition of methodological procedures; Data Collection; Literature review; Statistical analysis; Analysis and interpretation of data; Critical revision of the manuscript; Manuscript writing.

Cristiane Chaves Gattaz: Definition of research problem; Development of hypotheses or research questions (empirical studies); Definition of methodological procedures; Literature review; Analysis and interpretation of data; Critical revision of the manuscript; Manuscript writing.

David V. Gibson: Literature review; Statistical analysis; Analysis and interpretation of data; Critical revision of the manuscript; Manuscript writing. 